\title{
5 Territorial and Transterritorial Economic Actors in Early Historic South Asia
}

\section{Introduction}

The period between 300 BCE to $300 \mathrm{CE}$ is one of change and, in general terms, growth, which was the result of cooperation of different sociopolitical participants in the economy. ${ }^{1}$ This chapter discusses the major actors that participated in and influenced various economic functions in early historic South Asia. The purpose here is to briefly introduce those engaged in different economic behaviors of production, consumption, acquisition, and redistribution of goods, services, and knowledge. As these behaviors are not strictly exclusive, this chapter is organized to highlight the capacities (individual or collective) in which the actors direct their wealth and pursue their economic goals. Here, the emphasis is on who are the actors and what are their functions in the economy. The questions about the structures within which these actors operated, and the various institutions they developed are discussed in my chapter below. ${ }^{2}$

Structurally, this chapter organizes the actors based on their geographical scope of operation and radius of interaction, moving from smaller to greater spheres of influence. Within this trajectory, I alternate between actors with a clear territorial base and those with a transterritorial presence, which do not necessarily have a physically identifiable core tied to a territory or locality. I begin with the domestic households at the core of the economy, which were the most basic production and consumption units in addition to being the primary provider of human resources to all other socioeconomic organizations. I then go on to discuss the providers of manual labor, who were the first point of contact for fulfilling the labor demands of a household that cannot be fulfilled by the members of the household themselves. Therefore, while the household was an institution with a core, its transterritorial counterparts were the manual laborers. Local elites could be both territorial, when their wealth was based on agriculture; and transterritorial, when their wealth was based on trade. Mercantile and professional corporate bodies, and their territorial counterparts, settlements and cities, were more complex organizationally and operated over larger distances. Finally, the Buddhist monastic system and the monarchical state had the largest spheres of economic influence. The institution of state was bound to a dynasty and its territorial boundaries, while in contrast the monasteries had a pan-Indic presence, and a network of transmission and connection without capitals or administrative centers, surviving through political changes and the rise and fall of dynasties.

1 Dwivedi, ch. 14, this volume.

2 Dwivedi, ch. 10, this volume.

○ Open Access. (C) 2022 Mamta Dwivedi, published by De Gruyter. (c) BY-NC-ND This work is licensed under the Creative Commons Attribution-NonCommercial-NoDerivatives 4.0 License.

https://doi.org/10.1515/9783110607642-008 


\section{The Household}

In this section, I emphasize that the institutionalized household was the basic social and economic unit, which lay at the core of the economy. Literary sources conspicuously identify and emphasize the economic importance of households in society at large. A household was the basic institution because, first, most property transfers occur within households or in moments of household transformation. Second, households were consumers, not only involved in subsistence consumption, but also in their demand for goods to fulfill their ritual duties and express their social standing. Last but not the least, households were involved in production processes, both agriculture and crafting activities, either as producers themselves or as providers of human resources to these sectors.

\section{II.1 A Normative Household: An Institutional Anchor of Private Property}

The representation of the household as an institution is already visible in texts from the middle of the first millennium $\mathrm{BCE},{ }^{3}$ and therefore for the period of our concern, the household and its role in society are well theorized in the literary sources. A household, i.e., grha, was a special setting in which members were bound together by their ritual roles that defined their involvement in production, reproduction, and social linkage. ${ }^{4}$ The household is presented as one of the four stages in life for men, that is, the âsrama system. The âśrama, a social institution regulating the socioreligious life of a man, divides his socioritual life into four successive stages, i.e., student, householder, hermit, and anchorite/renunciant. ${ }^{5}$

The householder (grhastha), the second, stage of a man's life begins with his marriage. In ancient texts, the ritual duty of marriage, like all ritual duties and activities, is explained in an economic context. After marriage, both men and women gain the position of a legal entity eligible to participate in economic and legal contracts, but before this, a male 'student' is a minor and therefore cannot hold property or make transactions. The Arthaśāstra emphasizes, "all transactions presuppose marriage" (vivāhapurvo vyavahāra). ${ }^{6}$ Marriage, the first contract that a person enters into, is also conceived of as a means of property transfer between house-

3 Here, the reference is to the Grhyasūtra literature, which discusses the daily and occasional rituals to be carried out in a household. See Tyagi 2007; 2008.

4 Tyagi 2008, 8.

5 The life stages are brahmacāri (student), grhastha (householder), vānaprastha (hermit), sanyāsin (renouncer). For a historical study and bibliography of the development and changes in the conceptualization of the âśrama system in the Indic literary tradition, see Olivelle 1993.

6 Kauțilìya Arthaśāstra (KA) 3. 2. 1. 
holds. ${ }^{7}$ Gifting of daughter, kanyādāna, is the essence of a legal marriage. ${ }^{8}$ The direction of money transfer and other items identify the type of marriage, which is of eight types. ${ }^{9}$ The superior forms of marriages are when the girl is gifted along with jewelries or cattle, ${ }^{10}$ while any form where there is no gifting of daughter is a relatively inferior form of marriage. The three most inferior forms of marriage are where bride price is accepted (ślkadāna), where the girl is forcibly seized, and where she is seized or violated when asleep or under the influence of intoxication. ${ }^{11}$ The type of marriage also determines whether the husband and wife have a common property or it remains separate, as in the case of the lowest form of marriages when the husband may not use the wife's belongings.

A woman's possessions (strìdhana) consist of various forms of payment and items. ${ }^{12}$ The wealth of a woman consists of $v r t t i$ (maintenance by her husband ${ }^{13}$ or livelihood $)^{14}$ and äbandhyam (ornaments). ${ }^{15}$ There is no limit to the ornaments she could possess, however, vrtti may not exceed more than 2000 panas. ${ }^{16}$ A woman's property consists of payments or gifts from her relatives at the time of or after marriage. Again, it is with the marriage or entering the stage of a householder that a woman too acquires the status of a legal entity.

Additionally, the reproductive role of a household is celebrated in many normative texts. ${ }^{17}$ In norms, the importance of the reproductive role of a woman is greatly emphasized. In fact, the most important role of the wife is to bear a son, for which a woman (strī) is equated with Śrī (the goddess of fortune). ${ }^{18}$ Moreover, even a servile bonded woman, along with her entire family, gets manumitted if she bears children of the master. ${ }^{19}$ Kautilya's normative text even brings the state into the matters of reproduction within households. He emphasizes procreation as the main purpose

7 Other defined topics are various types of pious (also legitimate) and impious (also illegitimate) marriages, qualities of an appropriate wife/husband befitting the ritual, economic, and social status. For a brief discussion on the institution of marriage in the śāstric tradition, see Jamison 2017.

$8 K A$ 3. 2. 2.

9 For the types of marriage see Jamison 2017.

$10 K A$ 3. 2. 2, 4.

$11 K A$ 3. 2. 7-9. Kautilya mentions that the first bride price (ślka) is taken by the parents, while the second, from the second marriage, is taken by the bride herself (KA 3. 2. 11, 12). See Kangle (1969) 2014b, 227; Olivelle 2013, 588.

12 See Kangle (1969) 2014b, 230. See also Olivelle 2013, 184.

13 Kangle translates vrtti as maintenance a woman receives from her husband. See Kangle (1969) 2014b, 228.

14 Olivelle translates vrtti as livelihood. See Olivelle 2013, 183.

$15 K A$ 3. 2. 14.

$16 K A$ 3. 2. 15. The limit of 2000 panas to be given to the women during marriage is also mentioned in Kātyāyana's vārttika, 902.

17 Gautama Dharmasūtras 3. 1-3, trans. Olivelle 1999, 83. Modern scholars also study the householder in comparison to the renunciants, see Heesterman 1982; Thapar 1982.

18 Manusmrti (MS) 9. 26.

19 KA 3. 13. 23-24. See also Jaiswal 2001, 57. 
of marriage, and thus in case of concealment of period or a man's failure to approach his wife at the right time, may lead to a fine of 96 panas. $^{20}$

The literary sources give an impression of the involvement of a wife in the management of the house, including keeping the accounts of expenses. Manu recommends that a husband should employ the wife in collection (samgraha) and disbursement (vyaya) of his wealth in cooking, cleaning, meritorious activity, and looking after the household. ${ }^{21} \mathrm{~A}$ wife is responsible for not only the needs of the husband but also the household in terms of looking after the vegetable garden and orchards. ${ }^{22}$ While the aesthetic importance for the maintenance of these flower gardens is mentioned, the number of spices, herbs, crops, and vegetables to be grown also has a great deal of economic significance to it. She is to have the knowledge of sowing and a sense of seasons of planting. ${ }^{23}$ Gardening is one of the aspects of the 'Sixty-four Arts,' and so is the knowledge of handling expenses. ${ }^{24}$ An ideal wife is to have the market knowledge of household goods as well as luxury items. The wife is to buy household commodities and stock up when the price is right. These are

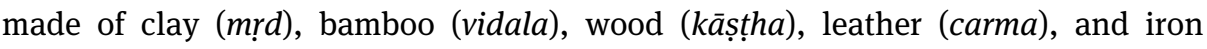
(lauh). ${ }^{25}$ There are also commodities that are to be bought, stocked, and kept hidden such as salt, oils and hard-to-get perfumes, spices, and medicines. ${ }^{26}$

\section{II.2 Consumption in the Household: Domestic Budget and the Role of Women}

Here, I emphasize that the household and its expectations were particularly important in influencing women's consumption. Women are commonly mentioned in the context of their role as wives in the household, be it in the context of royal households or laity: first, as consumers of luxury, and second, as those spending money on donations and ritual activities.

Early historic art conspicuously represents well-dressed and highly adorned women in their representations in sculptures and relief art. ${ }^{27}$ Archaeological finds, too, have brought forth a large variety of jewelry and beads from the habitational sites in the northern region of the subcontinent. Moreover, from the southern part of the subcontinent, megalithic burial deposits have also yielded a variety of jewelry

20 KA 3. 2. 44.

21 MS 9. 11.

22 See Kāmasūtra (KS) 4. 1. 1-8.

23 For the list of recommended plantations see KS 4. 1. 6-7; KS 4. 1. 29.

24 The 'Sixty-four Arts' are a set of skills that qualified one as cultured. It includes a variety of crafting, vocational, social and sexual skills. For the complete list, see KS 1.3.16.

25 KS 4. 1. 27.

26 KS 4. 1. 28.

27 P. Thakur 2018. 
items of personal adornment. ${ }^{28}$ Normative texts emphasize adornment and grooming for women. A wife should wear gorgeous jewelry, scented oil, and a dazzling dress when she goes to her husband to make love. ${ }^{29}$ Even the recommended everyday attire includes thin and fine clothes (dukūla) and the wife should moderately decorate herself with jewelry. ${ }^{30}$ It is not surprising that jewelry constitutes a very important part of a woman's property in the literary sources.

Even when women were consuming in nongendered ways, they identified themselves with reference to the male members of their household. Women participated in large numbers in the popular culture of consumption through donations as betrayed by epigraphic evidence. For example, a study of 518 donative inscriptions from Sanchi, dating between the mid-second century BCE and later decades of the first century BCE, revealed that almost 50 percent of donations to the monastery were made by women. ${ }^{31}$ They identify themselves either as nuns of the Buddhist order or with their roles within the household. In epigraphic evidence, patron women seeking merit for their family through donations identify themselves in the inscriptions by their household status, such as sārthavāhinī (wife of caravan leader), bammanī (wife of a Brāhmaṇa), kuṭumbinī (housewife), mahāsenāpatinī (wife of a military general) among many others. ${ }^{32}$ The donations women could make for the spiritual merit of their family shows their access to wealth and finances.

\section{II.3 Households and the Processes of Production}

Households were important participants in the production process as direct producers and suppliers of skilled and unskilled labor. The household was also the basic taxable unit, as the revenue officer, gopa (head of five to ten villages) was supposed to keep an account of the income of every household. ${ }^{33}$ Here, I will discuss the agricultural household and artisanal households as producers and transmitters of traditional knowledge through generations.

\section{II.3.1 Participation of the Household in Agricultural Production}

Familial relationships within the household structured both property rights on land and agricultural production. Most of the agricultural land was owned by private

28 Srinivasan 2018.

$29 K S$ 4. 1. 24.

30 KS 4. 1. 25. Doniger and Kakar $(2002,95)$ translate the term dukūla as "silk."

31 Milligan 2019. Even though about 40 percent of female donors identify themselves as nuns, 60 percent of female donors are lay women.

32 Various inscriptions in Lüders 1912.

33 KA 2. 35. 2-5. 
households, although we are also aware of agricultural land held by the crown and monasteries. ${ }^{34}$ With our current source base, it is difficult to discern the size of an average agricultural holding. We learn of small agricultural holdings where the owner may have managed the land with the help of family members and seasonal wage laborers (sec. III). We also learn of the kutumbikas (members of a family) and grhapatis (lords of household), ${ }^{35}$ who were landowning economic elites known from both textual and epigraphic sources. More specifically, kuțumbikas were kin-based agrarian householders. At times, records report they were well off, and engaged in religious donations and moneylending. ${ }^{36}$ The grhapati was an exceptionally rich local elite, whose wealth marked him out from his extended kin (sec. IV). However, both kuṭmbikas and grhapati are to be distinguished from tillers of lands, who were rather called kinasa, krșivala, karșaka, and halikas. ${ }^{37}$ It is possible that these were farmers with their own land and tools.

Households had access to additional labor. From the Arthaśāstra we also learn about tenants and hired laborers. Tenancy was also marked by the practice of sharecropping. We have reference to the female agricultural laborers, ardhasitikās, ${ }^{38}$ who tilled the land for half the produce. Jaiswal suggests that this category is hardly visible in other ancient sources and is seldom taken into consideration. ${ }^{39}$ She further points out that these women had some sort of financial independence, who along with women of cowherd communities (gopālaka) shared financial responsibility in the debts incurred by their husbands. ${ }^{40}$ Texts also note the involvement of women in sowing, weeding, transplanting, harvesting, and processing the crops. ${ }^{41}$

\section{II.3.2 Artisanal Households}

Archaeological finds have shown that a majority of the craft activity took place at the household level. An example is that of the potter's household from Indor Khera (Uttar Pradesh), where the workspace and residential complex are found at the

34 We also learn of royal land, see Dwivedi, ch. 10, II.1, this volume.

35 The connotation of household here is of a holding larger than the conventional household ( $g r h a$ ), and therefore he is to be distinguished from a householder, grhastha (secs. II.1 and IV).

36 R. Chakravarti 1996, 181-186.

37 R. Chakravarti 1996.

$38 K A$ 3. 13. 9. Krishan Rao $(1953,143-144)$ considered them similar to the landless laborers who worked in cultivating the "crown lands" and who paid one-fourth or one-fifth share of the produce as land rent. While the tenant/sharecropper status on agricultural field of the ardhasitik $\bar{a}$ is also pointed by both Kangle ([1969] 2014b) and Olivelle (2013), the rent amount is debatable, as the latter scholars consider the share to have been half of the produce.

39 Jaiswal 2001, 53.

40 KA 3. 11. 23; Dwivedi 2015, 120-121; see also Jaiswal 2001, 53.

41 KS (Kāmasūtra) 5. 5. 6-8. See also Jaiswal 2001, 52, 53. 
same place. Production space for ceramics can be identified relatively more clearly than other craft activities, not only because of the durability of the final product, but also because of the presence of easily identifiable tools and equipment, such as anvils and dabbers, firing facilities, lumps and rolls of clay, deposits of sand used for tempering, unbaked artifacts, wasters or over-vitrified material, etc. ${ }^{42}$ The rudimentary and miniature terracotta and clay objects found at the potter's site have been used as an indicator of children participating in learning activities related to the craft. ${ }^{43}$ If we are to consider this case, it is possible to assume that some, if not all, of the craft skills were transferred within the family. ${ }^{44}$

Residential workshops are also mentioned in the literary sources. The term antarāpana (interior shop) perhaps refers to the workshop at a private residence and the items could be directly sold from the place of its production. ${ }^{45}$ Additionally, these workshops were often found in clusters in their respective areas. An example commonly cited is that of the goldsmiths, who had their residence-cum-shop located together, and the street was named after them. ${ }^{46}$ Households are therefore also economic institutions where members form the basic work group in both agricultural land or manufacturing units owned by a household. The individuals involved are primarily bound by ritual and kinship ties. However, households also reached out to other groups at times for additional labor requirements.

\section{Manual and Menial Labor}

This section discusses the general labor system(s) of early India by identifying the social categories that shaped the provision of manual labor in different economic settings, ranging from wage-earning laborer in agricultural and crafting industries to subservient laborers working in domestic, royal, monastic, and corporate organizations. Unlike in the Graeco-Roman context, an institutionalized system of slavery did not shape the labor profile of early India. Indeed Megasthenes, the Seleukid ambassador to Candragupta Maurya's court, found it noteworthy that India had no slavery. ${ }^{47}$ In the Indic context, the slave-free dichotomy did not play the same fundamental structuring role as it did in Graeco-Roman society. This does not mean

\footnotetext{
42 Varma and Menon 2015, 36-42.

43 Varma and Menon 2011.

44 The authors have also made other ethnoarchaeological studies of the household involved in pottery production. Their studies show a presence of a very long tradition of pottery production and children learning while playing within similar premise. Varma and Menon 2011; 2015.

45 Schlingloff 2013, 14, n. 10.

46 For the street of 'gold dealers,' see KA 2. 13. 2 with Olivelle 2013, 537.

47 Diodorus Siculus 2. 39. Absence of slavery was echoed in Arrian's and Strabo's writings as well. For a discussion, see Thapar 2013, 113-114.
} 
that subservient laborers were completely absent. There are instances of indentured and bonded labor, as well as a practice of offering labor for basic subsistence, which we shall discuss below. Rather, the stratification of society into socioritual groups with special economic roles, the varna system, was more important in defining labor roles. ${ }^{48}$

In normative texts, society is divided into four socioritual groups who are also recommended to perform specific economic functions. Südras, the lowest of the four varnas, are people who work with their hands. This includes craftsmen - such as ivory workers (dantakāras), masons (vadhaki), weavers (sotika), leather workers (cammakāra) - agriculturalists, and more inferior groups who performed manual labor. ${ }^{49}$ While the normative texts describe the Sūdras as primarily a group serving the other three varnas, epigraphic sources reveal that craftsmen could be part of professional associations and amass wealth on a scale that allowed them to commission carvings of caves and pillars as donations to the Buddhist monasteries. ${ }^{50}$ The normative texts also do not characterize the Sūdras as slaves. They could own property, possess agricultural lands, be tenants and sharecroppers, and importantly, did not have a master. ${ }^{51}$ Moreover, it is noteworthy that they are paid wages unless they perform voluntary works or are reduced to bonded labor in the case of failure to repay their loans. Daily wagers are on the lowest rung. The king is instructed to pay the daily allowance (pratyaham kalpayedvrttim) for these laborers on the basis of their "rank and duties," where the minimum is one pana and the maximum wage is set as six panas along with bhakta (payment in kinds) in the form of clothes every six months and one drona of grain every month. ${ }^{52}$

Apart from the Sūdras, which is one socioritual umbrella group of manual laborers, we hear of other categories defined by an unequal relationship of subjugation on the provision of labor. These are dāsas, as well as karmakaras and porisas. ${ }^{53}$ A person could enter such a condition of subservience in a variety of ways, by failing to pay their debts or being pledged for an unpaid debt (ädhāna), ${ }^{54}$ failing to pay fines or being sentenced to drudgery, ${ }^{55}$ being captured in war, purchased, or simply

48 Thapar 2013, 113.

49 The other three are: the Brāhmaṇas, who are the priests and educators; the Kṣatriyas, who are the ruling and warrior section of the society, and; the third are the Vaiśyas, who are agriculturists and merchants. We are not sure how strictly hierarchized these groups were, as to an extent the strictly hierarchical socioritual status is a modern historiographic topos.

50 Lüders 1912, nos. 29, 92, 95, 331, 345, 1005, 986, 1177, 1273. See also Basant 2012, 299-348; Shimada 2013, 238-242.

51 Sahoo 2012-2013.

52 MS 7. 126. Drona is one of the measures adopted in the Manusmrti. Olivelle (2005, 997) suggests that it could be five liters or approximately $9.5 \mathrm{~kg}$.

53 Sharma 1990, 165-166.

54 Kauṭilya discusses the issues of $d \bar{a} s a s$ and those pledged ( $\bar{a} d h \bar{a} n a)$ on their own or by others in chapter 13 of book 3.

55 See MS 8. 415. 
born into it. ${ }^{56}$ These groups are mentioned in a wide range of contexts implying varied degrees of subservience. ${ }^{57}$ The degree of servility can be determined by looking at the various conditions to which a laborer could be subjected, including but not limited to susceptibility to forced and unpaid labor, and loss of some legal agency by being treated as a property or commodity that could be transferred by sale or gifting.

The dāsas are a well-known subservient group who were used to perform menial labor. Their subjugation can be understood in terms of the "bundle of property rights" that identifies the rights of property and ownership in relation to those of others. ${ }^{58}$ The three applicable determinants can be a) rights that masters have over a dāsa, or his labor, b) rights of a dāsa to hold property, and c) legal recourse in case of violation. Masters could have some property rights over dāsas. They commonly appear in a list of items indicating wealth along with chariots, horses, and similar items denoting affluent lifestyle, suggesting the master had the right to use their labor. Moreover, masters could transfer their property rights, as we learn about the sale and purchase (kraya vikraya) of dāsas, and they could be inherited (dāyāgata) and even be acquired as gift (labdha). ${ }^{59}$ Another type of laborers who could be gifted are the ārämikas. The vinaya texts refer to the ārämikas, in the context of hundreds of workers involved in the upkeep of the monasteries and related buildings. ${ }^{60}$ Indeed, Buddhist monasteries may have been one of the biggest organizations using servile labor or at least benefiting from unpaid labor. ${ }^{61}$

Unlike chattel slaves, however, dāsas had property rights of their own. The concept that an arrya $a^{62}$ should not be reduced to the status of a dāsa, especially minors, ${ }^{63}$ suggests that there may be an implied loss of property associated with becoming a dāsa, but there is no clear instruction that a dāsa must be deprived of his property or ineligible to hold it. Moreover, there does not appear to be any legal restriction on earning an income and acquisition of property for dāsa. We even know of the property of the dāsa (dāsadravya), which goes to the master after him, and in case there is no master, the kinsmen shall inherit it. ${ }^{64}$

56 U. Chakravarti 2006, 72.

57 U. Chakravarti 2006, 70-75.

58 For the theoretical framework behind this approach of property rights, see Furubotn and Richter 2005, 81-86.

59 See Ghoshal 1944, 93; also, KA 3. 13. 20.

60 Chanana 1960, 82-84; Schopen 1994, 198-212.

61 Here the intended reference is to the story of a prince gifting to a monastery 500 ārāmikas for the maintenance of the monastery and monastic residence, Schopen 1994, 198-212.

62 In the $K A$, arya refers to the members of the four socioritual groups (varnas) (KA 3. 13. 1). Nor are any members of the four varṇas (Śūdra, Vaiśya, Kṣatriya, and Brāhmaṇa) to be reduced to slavery or they are entitled to fine (KA 3. 12. 1-4) It also means an esteemed person with superior, noble origin, see Apte 1993, 229.

$63 K A$ 3. 3. 1; 3. 13. 1.

$64 K A$ 3. 13. 24. In the later śāśtras, from the Manusmrti onward, the slaves do not have property rights and whatever they make belongs to their owner. 
Not only did dāsas have legally recognized kinship bonds, but subservient laborers also enjoyed some legal protection, especially those indentured as pledged security for debt. The pledged worker is considered capital (mūla) by Kautilya, so any abuse of them is equated with loss of capital. We hear of manumission (mokșa) of female workers in case they have been sexually exploited by their masters. ${ }^{65}$ The pledged person also gets his or her freedom on account of sexual exploitation or when forced to perform certain condemnable tasks. ${ }^{66}$ Although in theory a subjugated laborer had some kind of protection from violations and option for legal recourse, mentions of laborers escaping and peasants protesting indicate that the reality may not have been rosy. ${ }^{67}$

\section{Local Elites}

Although the literary sources talk mostly about the upper sections, the problem of defining the functional elite in India has been pointed out by scholars. ${ }^{68}$ The elite status of a person or group in early India may be evaluated from two positions, the status derived from ritual or ideological power and that from the politico-economic power. ${ }^{69}$ Thapar suggests that the elite could have come from the first three orders of the varnas (socioritual status). ${ }^{70}$ To some scholars, the warrior and the priest class appeared as the clear elite groups, as they enjoyed power. ${ }^{71}$ However, the forms of power these two groups enjoyed were often non-economic in nature. Also, since the varna stratification cut across the economic lines, Thapar suggests that

$65 K A$ 3. 13. 9.

$66 K A$ 3. 13. 9, 11.

67 For instance, see Mandal 2007.

68 Thapar (1978) 2006b, 109-136. The term 'functional elite' is often used by scholars in context of the modern world, and most commonly in the Marxist history writing where it is comparable to the upper class of the society. However, the structural functionalism was developed into theoretical framework by Durkheim. The functional elite theory agrees to the idea of circulation of elites in the society based on the changing power dynamics. A functional elite, therefore, is one who holds power and does everything necessary to keep it, while the non-power-holding elite strives for it. For further discussion, see Kocks 2016, 94.

69 Thapar (1978) 2006b, 113.

70 The varna system is characterized by ordering of society into four socioritual groups in the society, where each group has their respective prescribed economic, social, and ritual roles. Considering this order of society, many historians identify the economic elites with the upper sections of the order - Brāhmaṇa, Kṣatriya, and Vaișya, wiz., the intelligentsia, warrior, and merchant groups, respectively.

71 Cohen 1964. Cohen in this article brings forward the discussion about the status of the two varnas, which he calls two upper classes, Brāhmaṇa and Kṣatriya (priests and warriors respectively). 
the understanding of the category of the elite is varied. ${ }^{72}$ Being a part of high ritual status did not ensure economic prosperity, as we are aware of impoverished Brāhmaṇas from various narrative texts. Additionally, in prescriptive texts like the Manusmrti, amassing of wealth by a Brāhmaṇa is condemned. The only group that is encouraged to amass wealth is that of the Vaiśya ritual status, who are traders and producers, coming from a variety of occupational groups and economic conditions. ${ }^{73}$ In this condition, it shall be problematic to determine one ritual group as elite, or at least as economic elites capable of mobilizing and acquiring material resources. The distribution of economic power in the society indicates a situation of heterarchy. ${ }^{74}$

So, is there any category that can be easily identified as the economic elite in early India? The answer is yes; we can locate economic elites by identifying certain basic economic functions they fulfilled. They are identified as those who a) amassed wealth, b) had the potential to mobilize resources, both in agricultural and mercantile contexts, c) hired specialized and nonspecialized laborers, and d) were often seen cooperating and coordinating with prevalent religious organizations as well as by their political alliance to elevate their social and economic position. Grhapatis and śreșthis are the most visible titles indicative of elites in a socioeconomic context.

Grhapati, in Sanskrit and gahapati in Pali, commonly appear in textual sources between the sixth century BCE and fourth century CE, and from the second century BCE in epigraphy. This term means 'lord of household,' where the term grha means a house and pati means lord. However, grhapati is to be differentiated from a mere householder, grhastha (sec. II.1). The term grha in grhapati has a larger connotation than just a domestic household; it could be similar to a business house or an economic holding. Gahapati, the Pali version of the term grhapati, is also seen as an exalted title fit to be assumed by a man of social preeminence and considerable wealth. ${ }^{75}$ As a title or epithet, gahapati was assumed by a person with growing wealth and reputation, which marked him out from his extended kin. ${ }^{76}$ Loss or relinquishment of property would mean one could no longer be called a gahapati. The wealth of a gahapati consisted fundamentally of land, gold, and silver, as well as grain and cattle. A gahapati has a good presence in the agrarian setting. ${ }^{77}$ It is often suggested that they could have been the major taxpayers. One of the passages often cited is that from a Buddhist text, the Digha Nikāya, which identifies a gaha-

72 Thapar (1978) 2006b.

73 MS 10. 74-80.

74 The concept of heterarchy allows to perceive the fluidity in the structure of the society, where both relatively ranked or unranked elements interact. The flexibility of power relations and dynamic interactions is therefore considered as a ground for potential space where social changes can originate from within. See Smith 2006.

75 R. Chakravarti 1996, 181.

76 R. Chakravarti 1996, 184. See also Wagle 1995, 152.

77 U. Chakravarti 1996. 
pati as "one who pays taxes and thus increases the king's wealth."78 A gahapati, in the Pali texts, is associated with hiring dāsa-kammakaras (sec. III), and the latter is a group of manual labor and actual producer, as discussed above. The gahapati is considered an appropriator of resources, while the dāsa-kammakaras produced the surplus that the gahapati collects and redistributes. The title gahapati is also found in various donative inscriptions in the subcontinent. ${ }^{79}$ In one of the donative inscriptions, the donor is a woman who identifies herself as the wife of the brother of the gahapati named Patițiya. ${ }^{80}$ This type of identification makes it clear that gahapati is not a regular householder, but an important title, and any association with one brought status.

Another significant member of the economic elite was the śreșthi (Pali sețthi), who is identified as an immensely wealthy merchant with prominence in the mercantile community. It is suggested that a śreșthi could have been a banker or a leader of a guild. ${ }^{81}$ As a mercantile designation, the term is also found in various donative inscriptions from the second century onward. Among the titles of prominent merchants, of particular importance is the rājaśreșțhi, who perhaps held an unpaid office in the court of the king, appointed by or closely associated with the ruler. ${ }^{82}$

The Buddhist texts refer to the importance of an amicable relationship with the rulers, and how the gahapatis are one of the seven treasures of the king's symbol of sovereignty and intrinsic to kingship. ${ }^{83} \mathrm{We}$, however, come across a different perspective as well. One famous example is that of the famous merchant (setthi), Anāthaindaka, who bought a garden by paying the number of coins that could physically cover the entire surface of the garden, i.e., 10 million coins. Anāthaiṇạka had to pay this price because Prince Jeta refused to sell the garden and rather mockingly challenged the merchant for this kind of payment. ${ }^{84}$ Suspicion and scorn toward the merchants is also seen in the Arthaśāstra, where the king is recommended to be wary of wealthy merchants and keep surveillance over merchants. The policy toward merchants is discussed under the title of "kanțaka śodhana," which literally means "Eradication of Thorns." 85 It may be taken as the state's recognition of the fact that the wealthy merchants pose a threat to the authority of the rulers because of their potential to mobilize resources against the state's authority. In addition, the śreșthis as leaders of professional associations also exercised their economic influence in various ways.

78 U. Chakravarti 1996, 161-162.

79 Lüders 1912, inscription nos. 193, 201, 202, 449, 450, 725, 908.

80 Lüders 1912, inscription no. 450. There is also another donative inscription where gahapati Patițiya himself is mentioned as a donor (Lüders 1912, no. 449).

81 Sircar 1966, 317. Neelis 2011, 24.

82 R. Chakravarti 2007, 102.

83 Anguttara Nikāya, 3:75-76; Digha Nikāya 1:27, vide U. Chakravarti 1996, 161.

84 Cullavagga 6. 4-9, trans. Horner (1952) 2001.

85 KA Book 4. 


\section{Merchants and Corporate Bodies}

Professional corporations were important actors of transterritorial activity in early South Asia. Corporate bodies were formed by all kinds of professionals involved in manufacturing, finance, and trade. This section starts with merchants before turning to the discussion of a wider range of corporate bodies in early historic India.

\section{V.1 Merchants}

$\operatorname{Vanik}(a)$ is the most common term for traders in both Sanskrit and Tamil texts. Epigraphic records in Tamil-Brāhmī show the presence of specialized traders, such as oil traders (ennai vanikan), textile traders (aruvai vanikan), ploughshare traders (kolu vanikan), and many others. ${ }^{86}$ This coincides with the fact that markets were organized into streets dedicated to traders dealing in specialized items. ${ }^{87}$ Local traders were either independent peddlers (vaidehakas), retailers (pratiketr) operating at the village or city level, local agents (upajī $v \bar{a} h$ ) of bigger merchants, or artisans who sold their goods directly from their workshops (antarāpana). ${ }^{88}$ They were distinguished from nonlocal merchants (āgantuk/ägantum) who, within the provisions of the Arthaśāstra, were allowed a higher profit margin and had access to legal protection in certain cases. ${ }^{89}$

Long-distance traders were specialized either in overland travel with oxcarts and porterage animals, or in maritime trade across the Indian Ocean. Some caravans transported particular commodities, as is suggested in a Sangam text mentioning salt-trading caravans (umanaccāttu), ${ }^{90}$ while others moved composite cargoes. ${ }^{91}$ Both caravan and maritime traders seem to have been organized in corporate bodies, as they appear in various literary and epigraphic texts in connection with a leader, sārthavāha. ${ }^{92}$ Two inscriptions from Vellari and Madurai refer explicitly to merchants organized in corporate bodies (nikamatōr). ${ }^{93}$ Moreover, many TamilBrāhmī potsherds found at sites on the coast of the southern Arabian Peninsula, as well as at coastal sites in present-day Thailand, bear the names of traders, suggesting that long-distance traders habitually acted together when trading abroad. ${ }^{94}$ All

\footnotetext{
86 Rajan 2019, 183.

87 See Dwivedi, ch. 14, IV.3.1, this volume.

88 Again, Dwivedi, ch. 14, IV.3, this volume.

89 KA 2. 16. 11-14.

90 Champakalakshmi 1996, 106.

91 Dwivedi, ch. 14, III.2 and IV.1-2, this volume with Coningham et al. 1996, 89-92.

92 Dwivedi, ch. 14, IV.1, this volume. For further detailed references, see Neelis 2011, 25-29, 31-33.

93 See also sec. VI.2.2.

94 Rajan 2019, 183 for this and further evidence. For further reference, see also Dwivedi, vol. 1, ch. 10.A, 441-444.
} 
this has been taken to suggest that both local retailers and long-distance caravan and maritime traders acted in collectives to share risks and profits. ${ }^{95}$ This notion gains support when considered within the wider evidence for corporate bodies and associations.

\section{V.2 Corporate Bodies and Associations}

Private professional organizations are one of the most widespread economic actors in early historic South Asia. ${ }^{96}$ They are identified by the very common generic term śreni, best translated as corporate body, or cooperative organization. These corporate bodies inevitably have been compared with medieval European guilds. ${ }^{97}$ However, since the evidence does not allow to reconstruct the internal administration and functioning of the ancient Indian corporate bodies, any comparison with the medieval European guilds should be avoided. Instead, I emphasize that the sreni system was a form of economic cooperation which mitigated the risk factor for both members and clients, developed credit institutions, and served as a network of knowledge transfer and intellectual exchange.

Srenis were private bodies of professionals of the same field. We learn of a variety of guilds, such as associations of garland makers, weavers, ivory workers, and woodworkers. There were even mercenary guilds, who were often hired in the infantry segment along with other soldiers, and the chief of this guild is among those recommended for high remuneration from the state. ${ }^{98}$ Guild offices had designated sections along the city walls in normative instructions for city planning. ${ }^{99}$ The nature, composition, and size of these associations varied. While these are a profession-based organization within a village, it is possible that settlements and even cities formed a part of a corporate body with administrative functions (sec. VI).

Guilds also had legal standing, and they may have managed codes and rules (śrenidharma) to regulate their internal affairs. These codes also had some validity outside their śreni, as they are to be taken into consideration by a king or judge

95 Rajan 2019, 183.

96 Ray 1986; K. K. Thaplyal 1996; Evers 2017, 148-171.

97 Seshan points that the inevitable comparison of the ancient Indian craft guilds with those of the Medieval European ones, was made "with the underlying inference that guilds came into existence in medieval Europe, but were present in ancient India." As guilds are an urban feature, it became important for the economic historians of India to demolish the ever-stagnant and everagrarian image of Indian past by highlighting the presence of guilds and cooperatives in ancient India. Seshan 2007.

$98 K A$ 2. 33. 8; 5. 3. 9; 7. 8. 32; 7. 14. 28; 8. 4. 27-29; 9. 2. 1, 4, 16. Kangle translates the śreni in reference to troops as "banded" soldiers, while Olivelle translates them as "corporate" troops. Kangle (1969) 2014b, 181; Olivelle 2013, 171.

$99 K A$ 2. 4. 16. For all Sanskrit references to the $K A$, see Kangle (1969) $2014 a$. 
when solving a dispute between two parties. ${ }^{100}$ Their legal standing may have also provided economic security to both the members and the clients, which perhaps was the main reason for the formation of these guilds. In context of artisanal guilds, the Arthaśāstra recommends acceptance of the raw material or monetary deposits only after the guarantee of the guild, and in case of any misfortune leading to nondelivery or nonpayment, the guild shall be responsible for the entrusted material. ${ }^{101}$

We also know of the involvement of these associations in commercial activities, and their potential to expend and invest in large capacity. The head of a guild is the śreșthi, the title also having the connotations of a rich merchant, financier, and banker, as we just saw. ${ }^{102}$ Like bankers, guilds lent capital and received deposits, as is clear from their involvement in managing endowments (below). Like other wealthy members of society (sec. IV), the śreșthi of guilds were donors to religious institutions. From Sanchi, 19 inscriptions with reference to sețți (Skt. śreșți) as donors have been found. ${ }^{103}$ From Vidisha as well, donations by śreșthi and his relatives have been noted. ${ }^{104}$

Apart from direct donations, the associations accepted endowments (nivi) on behalf of a monastery. Their potential for profitmaking is indicated in this practice. The guilds that accepted endowments forwarded a fixed share of their profit to the monastery on a monthly basis. One cave inscription from Nasik (Maharashtra) mentions monetary investments in two weavers' guilds, from which a fixed part of the interest generated was to cover the expenses for clothing and medicines of monks residing at the cave shelter. ${ }^{105}$ Similarly, inscriptions from Mathura refer to two śrenis that received endowments in cash for feeding Brāhmaṇas regularly. ${ }^{106} \mathrm{~A}$ similar example comes from a pillar inscription (ca. 250-300 CE) at Nagarjunkonda (Andhra Pradesh) that records a perpetual endowment (akhayanivi, in Skt. akșayanivi), the interest from which goes to paying various guilds, for the performance of various rituals at the temple. ${ }^{107}$ The payment is to be made monthly (masanumasi[ka]). ${ }^{108}$

100 MS 8. 41.

$101 K A$ 4. 1. 17.

102 The other variants of the term are śreșțin (Skt.), sețți (Prakrit), and srețhi (Gāndhārī). A Gāndhārī birch bark manuscript from Afghanistan, dated between 1-100 CE, refers to srețhiputra. https://gandhari.org/n_dictionary.php. Accessed on 24. 09. 2019. See more about setțhi as a local economic elite in sec. IV.

103 Basant 2012, 178, tab. 6.7. See also Lüders 1912, nos. 206, 207, 246, 255.

104 Lüders 1912, nos. 346, 248, 255, 283, 339, 348.

105 Nasik cave inscription of Riṣabhadatta, no. 38 in Mirashi 1981, pt. 2, 95-100. See also Lüders 1912, no. 1133.

106 V. K. Thakur 1987, 73.

107 For the inscription, see http://hisoma.huma-num.fr/exist/apps/EIAD/works/EIAD0056.xml, EIAD 56 (accessed on 25. 09. 2019). Here, Sarkar's old reading of the term [vi]dhi, and that of the vadhisa as suggested by Arlo Griffiths et al. both may connote to the term vaḍhi in Pali (vrddhi Skt.).

108 Here, masanumasi[ka] has been considered, as has been read by Arlo Griffiths et al. See http:// hisoma.huma-num.fr/exist/apps/EIAD/works/EIAD0056.xml, EIAD 56 (accessed on 25. 09. 2019). 
We also learn of corporations being formed among separate professional groups. These are negamas. The membership perhaps crossed through more than one profession, and they acquired administrative roles, including minting of coins and seals, in the city as well. For a discussion on these types of cooperatives found in the urban context with administrative functions, see section. VI.2.

\section{Settlements and Cities as Economic Actors}

Settlements and cities as economic actors were shaped by their geographical position, proximity to natural sources, and socioeconomic relations with neighboring and distant settlements. Here, I emphasize that cities and ports in South Asia developed within their highly connected 'settlement localities.' The discussion then focuses on the cooperative and corporate identities that villages and cities acquire.

\section{VI.1 Connected Settlements and Urbanism}

An increase in the number of cities is recorded in the early centuries CE. A large number of those are situated along navigable rivers, even the most celebrated of the port cities in Graeco-Roman sources, such as Barbarikon, Barygaza, Muziris, Arikamedu have been located at the mouth of riverine estuaries. ${ }^{109}$ The development of these port cities should be seen in connection with their productive hinterlands, which were well connected with other neighboring settlements. An important feature of settlements in early historic India was their clustering, which created urban zones. The emergence of 'settlement localities' has been identified in Mathura, Varanasi, Sanchi, Anuradhapura, and other important urban zones. ${ }^{110}$ The clustering possibly allowed the development of an urban zone even when the sites could remain smaller, at least in comparison to Chinese and Roman contexts. ${ }^{111}$ The size of urban sites in India ranged between 50 and 300 ha in the early centuries CE. ${ }^{112}$

The clustering is also noted in areas experiencing the megalithic phase in the eastern Deccan and the south, which are considered different from the archetypical urban zones in the north and the western Deccan. For example, a study of megalithic settlements from Tamil Nadu shows a presence of about 70 sites within a radius

Reference to monthly payment of interest also comes from various inscriptions discovered in the western Deccan. See Mirashi 1981.

109 Deloche 1983; 1994, 5-128.

110 See Dwivedi, ch. 14, III.3, this volume.

111 For example, for the megacities in Roman contexts, see Fabian and Weaverdyck, ch. 3.A, II.1, this volume. For Chinese imperial cities and structures, see Leese-Messing, ch. 6, II.1, this volume. 112 Smith 2006, 119. 
of about $20 \mathrm{~km} .{ }^{113}$ Those sites classified as large settlements were about five ha and were capable of supporting a population of 1,000. ${ }^{114}$ Within these clusters, the largest cities had particular roles, such as centers of administration and centers of contact in long-distance networks. Both these roles could be seen as a result of the coordination of operations between smaller settlements and cities.

The settlement localities allowed the zones to operate in cooperation, serving various requirements of the zone and enabling villages/sites to develop craft specialization. For example, archaeological finds from areas around the port city of Bharuch (Barygaza) have shown the presence of allied industries and commercial manufacturing centers producing cotton textiles, semiprecious stone beads, and glass beads. ${ }^{115}$ Settlements with occupational specializations are also known from the texts, as we are aware of villages of ivory workers (dantakāragāma), carpenters (vaḍdakigāma), sweepers or menial workers (caṇdālagāma), and fowlers and hunters (nesādagāma). ${ }^{116}$

The extended network of settlements is also visible in normative texts. From a state's perspective, the administrative unit is divided into a political core, fortified city (paura) and hinterland (janapada). ${ }^{117}$ An ideal countryside can protect itself (svārakșah), can sustain itself (svājīvah), is rich in resources and capable of bearing fines and taxes, and has irrigable land, agricultural workers with good ethics, forest resources, and land and water routes. ${ }^{118}$

A village ( $(\bar{a} m a)$ is seen as the basic administrative unit. In normative texts, a village that is founded by the state should have a minimum of 100 and a maximum of 500 families, with the majority of a population being Sūdra agriculturists. ${ }^{119}$ As suggested above, we also find villages identified by the specialized occupation of the majority of their population, such as a village of carpenters (vaḍhakigāma). At 800 villages, there is a 'provincial capital' (sthāniya). ${ }^{120}$ In terms of administrative division, there are three levels of administrative units between a collection of 10 to 800 villages. A similar structure is found in the Manusmrti, where the administrative units are set up at various levels. For example, administrative units that oversee 1, $10,20,100$, or 1000 villages. ${ }^{121}$

113 Moorti 1994, 16, 108.

114 Ray 2006, 114-115.

115 Ghosh 2014.

116 These references commonly appear in various jātaka stories in the Jātakatthavaṇanāa, see Cowell 1977. For the online database, see https://jatakastories.div.ed.ac.uk/.

117 For a discussion and further bibliography, see Basant 2012, 272-275.

$118 K A$ 6. 1. 8.

$119 K A$ 2. 1. 2. In the $M S$, a Brāhmaṇa is recommended not to take up agriculture as a livelihood as ploughing of land involves injury to other living creatures, MS 10. 83-84. For a discussion on agricultural laborer, see II.3.1 and III.

120 KA 2. 1. 4. Olivelle $(2013,99)$ translates the term sthānīya as a 'provincial capital,' while Kangle ([1969] 2014b, 56) mentions it as the headquarter of revenue officers.

121 MS 7. 114-119. 


\section{VI.2 Settlements and Their Identities}

The role of settlements as physical spaces that create a platform for interaction and economic exchange is important. They were anchors for setting up infrastructures, such as irrigation facilities, road and transport facilities, and physical market spaces that have been discussed elsewhere. ${ }^{122}$ Here, I focus on how villages and cities in particular developed cooperative and corporate identities, which provide an institutional framework for economic activities to be coordinated in early South Asia.

\section{VI.2.1 Villages as Socioeconomic Entities}

Villages had both internal and external economic roles. By appointing village headmen, they emerged as administrative entities regulating internal legal matters. They also organized themselves to exercise communal responsibilities. Within a village, the committee of village elders was responsible for managing and at times 'increasing' the property of the minors (bāladravyam) and property of the temple (devadravyam). ${ }^{123}$ Also, if one was away on a journey, a share of one's property was deposited with the village elders. ${ }^{124}$ They are also sought to witness any local transaction, division of property, and drafting of contracts. ${ }^{125}$

The economic roles of villages were expressed externally in their position vis-àvis other villages and in the hierarchical administrative structure with respect to the state. Some specialized villages, such as villages of hunters and fowlers (nesādag $\bar{a}$ $m a$ ) and menial workers (e.g., caṇ̂ālagāma), supplied the labor force for the cities. Another role of the villages, with respect to administrative hierarchies, was that of the basic unit of tax collection for a state official. ${ }^{126}$ The ideas of community ownership, accountability, and employment are also visible in the concept of unpaid labor (viști) offered by villages to the state for building fortresses, etc., often in lieu of taxes. ${ }^{127}$

\section{VI.2.2 Cities and Their Corporate Entities}

Cities have been classified based on their attributes even in the ancient literature. There are fortified administrative cities (paura), the port cities (pațtana), and cities

122 For infrastructure related to water management and transportation, see Dwivedi, ch. 10, VI, this volume. For organization of markets, see Dwivedi ch. 14, IV.3, this volume.

$123 K A$ 2. 1. 23.

$124 K A$ 3. 5. 19.

$125 K A$ 3. 9. 17.

126 See Dwivedi, ch. 10, II, this volume.

127 Sharma 1990, 166. Vișți is also interpreted as forced labor. 
as religious centers (tirtha). Other than being a part of the administrative hierarchy, many commercial cities developed their own corporate entities. Thakur considers the presence of city-coins as an indication of the corporate nature of some cities. ${ }^{128}$ Among the city-coins, the most noticeable ones are from: Ujjain, bearing the legend ujaniyi; Eran, with the legend erakanya; Ayodhya, with different legends ajudhe, ajadhe, or ajidhe; and, Tripuri, bearing the legend tripurī. ${ }^{129}$

Cities were hubs of different kinds of civic bodies. An example is the nigama, which carried out not only some of the administrative functions, but also made collective donations for merits. ${ }^{130}$ We are aware of city-based guilds and corporations called negama and naigama ('belonging to the nigama') from epigraphic evidence, such as reference to the Dhānyakațaka nigama in an inscription from Amaravati and four seals bearing "nigama" found at Bhita. Many inscribed potsherds also bear the inscription nikama or nekama, which can be associated with specific guilds or special civic bodies in early South Asia. The cities provided a framework within which the nigama could operate, but they were often not restricted to one city. A famous example comes from Taxila, where coins with the inscription pancanegama (a body of five corporations) have been found. The role of the negamas may also have been administrative in nature. ${ }^{131}$

Perhaps similar to the negama/nigama was the goșthi (Pali goțhi), meaning committee. In the KS, goșthi appears as an important circle (also association) of people, primarily the esteemed city-men (nāgaraka). As members of the goșthi, these refined citizens, were of equal means, intelligence, disposition, and age. ${ }^{132}$ There is a reference to a gothī of more than 35 members in an inscription on a Buddhist casket from Bhattiprolu. ${ }^{133}$ Another inscription mentions a treasurer (hirinakāra) of the committee. ${ }^{134}$ Gothis also made collective donations and investments, which is clear from epigraphic records by Bodhagoți and Vamdagoțhi from Sanchi and Amaravati, respectively. ${ }^{135}$ From Sri Lanka too, the epigraphic records mention donations by the head of a corporation called pūga at various instances. The heads of corporations identify themselves as the jeța (Skt. jyeșțha/śreșțha) and anu-jețe, ${ }^{136}$ who may have also functioned as influential local elites (see sec. IV).

In addition to the coordination function of cities, the idea of urbanity was closely linked to particular forms of consumption. The ethos of urban living is a notable

128 V. K. Thakur 1987, 71.

129 Allan 1936, cxxx, cxl; Lahiri 1974.

130 A donative inscription records a donation for the excavation of a cave and an assembly hall for the samgha by a corporate/civic body (negama). Mirashi 1981, pt.1, 172-173.

131 V. K. Thakur 1987.

132 Ali 2004, 65.

133 Lüders 1912, no. 1332.

134 Lüders 1912, no. 1333.

135 Lüders 1912, no. 234; Shimada 2013, 142.

136 Paranavitana 1970, xcix. 
aspect in the representation of urban spaces in literary sources. Nāgaraka, literally, who lives in a city (nagara), is distinguished from a village dweller, jānapada and grāmina (villager) in the literature. ${ }^{137} \mathrm{~A}$ city dweller is considered more sophisticated in the sense of the items he consumes and the services he has access to, for example, grooming and leisure activities. ${ }^{138}$ For a nāgaraka, social engagement with a village-based woman is considered condemnable and inferior. ${ }^{139}$ Even among monks, who might not live in cities, those "possessed of urban speech" (nāgaralapita) are more revered..$^{140}$

\section{The Monastery and Monastic Body as Economic Agents}

Schopen has pointed to the conspicuousness of material remains in the form of sculptures, coins, and architecture found at the religious sites:

... how is it that groups of ascetic, celibate men who were supposed to have renounced all wealth and social ties, left such largesse in the archaeological records; how is it that they, and sometimes they alone, lived in North India in permanent, architecturally sophisticated quarters, that they, and they alone, lived in intimate association with what we call art? ${ }^{141}$

From the second century BCE onward, architectural remains represent a structured and organized mendicancy. ${ }^{142}$ What had started with the renunciation of the social and family life by individuals, emerged as an institution with considerable social and economic power, drawing from the general practice of making religious donations (dāna) for merits. There is evidence for the samgha (monastic community) in the structural remains of the stuppas (apsidal shrines to house relics), caityas (worship halls), and residences for monks and nuns (vihāra and varșakas/upassayas,

137 Kāmasūtara (KS) 2. 10. 36-38.

138 A nāgaraka's lifestyle is extravagant and expensive. He is expected to spend on items of grooming and toiletries, which are: anulepana (fragrant ointment generally made of sandal wood paste), perfume and incense, use of alaktaka to redden the lips, use of oils for massage and shampoo for limbs (utsādana), and use phenaka (soap?) regularly. In addition, decoration of house and maintenance of vegetable garden and orchard are practices that are encouraged. KS 1. 4. 16-17.

139 KS 5. 5. 11.

140 Only a monk "speaking the language of those living in a city" (nägara-lapita) can be appointed as the Admonisher-of-Nuns. It is suggested that only they have elegant speech. Schopen 2010, 110111.

141 Schopen 2004, 19.

142 This was perhaps also true for Jaina monastic communities, but here I discuss specifically the Buddhist community. 
respectively). ${ }^{143}$ These architectural structures are found throughout the subcontinent - in the plains constructed with stone and baked bricks, and in the plateaued and highland regions as rock-cut monuments and excavated caves. These monastic centers became so grand that they housed a large number of monks and nuns, developed hierarchies within their order to manage the donations and construction, ${ }^{144}$ and had servile laborers working to take care of the daily chores and maintenance. ${ }^{145}$

The Buddhist monastic centers were nodes in a larger Buddhist network that were bound by the movements of monks and nuns. The pan-Indic presence of the monasteries and spread of Buddhism in Central Asia and Southeast Asia was an extension of religious as well as economic network, which also spanned centuries. ${ }^{146}$ The monasteries not only became centers of learning and recordkeeping, where the canonical texts could be compiled and reproduced, but as part of the monastic network, they also became transmitters of knowledge to different regions. ${ }^{147}$ The network enabled the transmission of ideas, information, and technologies, which were used and shaped according to the local requirements. ${ }^{148}$

\section{VII.1 As Consumers with Influences on Elite Consumption Patterns}

Monastic networks may have provided a vector along which elite consumption patterns might have spread. The main items used to honor and worship the Buddha and other sacred figures were merchandise traded in the Kuṣāna period, such as pearls, corals, lapis lazuli, silk, and other precious items. ${ }^{149}$ Because these items were considered precious enough to be donated to a monastery, they were also sought by the laity. The Mahāvastu encourages decorating Buddhist monuments in silk, and

143 Schopen 2008, 625.

144 From Kanheri, we find an evidence of monks taking the work of supervising and overseeing the construction of a caitya cave financed by a merchant family. See Mirashi 1981, no. 28; Lüders 1912, no. 987.

145 The reference here is to the ārämikas and kalpikāra working in the monasteries. A story from the vinayas refers to a gift of 500 ärämikas, who settled down with their families in a village near a monastery. A monk was also elected, called ārāmika-pessaka, to supervise the work of these ārāmikas. See Chanana 1960, 83.

146 Neelis 2011; Ray 2020.

147 Schopen 2004, 2. Many scholars identify the popularity of stūpa construction and worship of relic as a phase of the Mahāyāna school of Buddhism, which brought about the divination of Buddha resulting into worship of the Buddha and potential Buddhas (Bodhisattvas). See Liu 2009, 179182.

148 See also Dwivedi, ch. 14, this volume for cooperation between monasteries and mercantile groups.

149 Liu 2009. 
this form of worship promised worshippers a higher status and material gains. Likewise, the Mahāvastu references similar use of silk in urban and court life. ${ }^{150}$

\section{VII.2 Monastic Communities as Property Owners and Credit Institutions}

Even though individual monks were not allowed to possess property, we learn of corporate or communal property of the monastic community (samgha) from both Buddhist and non-Buddhist texts. ${ }^{151}$ These 'community assets' (sāmghika) were used for the restoration and repairs of the monastic buildings if they had not found a donor. ${ }^{152}$ Additionally, we learn of depositories (koșthikā) at the monastery that not only contained books, but also legal documents and money. ${ }^{153}$ Recovered sections of the Mūlasarvāstivāda-vinaya throws light on the storage of 'perpetuities' (akșaya) donated and stored in the koșthika of the monastery. Monastery as a center of wealth is also known from non-Buddhist texts. For example, Kautilya recommends in the Arthaśāstra that a king or prince should seize the wealth from pāṣāṇdasamgha (non-Brahmanical ascetic organizations) as a quick way to acquire resources in times of grave need..$^{154}$

Donors to monasteries came from different professional backgrounds and the types of donations monasteries received also vary greatly. The majority of epigraphic remains from early India record donations to monasteries, and the inscriptions have been found on architectural stone slabs, copings, pillars, and cave walls. Many of such inscriptions refer to the donation of caves, ${ }^{155}$ shares in agricultural fields, ${ }^{156}$ coconut saplings for the purposes of commercial farming, ${ }^{157}$ custom duties from a port, ${ }^{158}$ and the recurring interest from endowments. ${ }^{159}$ Also, some monasteries had servants and at times servile labor to take care of the regular maintenance of the residential complex and the prayer halls.

The monasteries perhaps also became the repositories of the wealth of members who joined as monks in the later stages of their lives. A sonless old man could join the samgha as a renunciant monk. The monastery could care for him in his days of

150 Liu 2009, 181-183.

151 Schopen 2004, 4; see also Morris, ch. 4, IV.2, this volume.

152 Schopen 2004, 27.

153 Schopen 2004, 51.

$154 K A$ 1. 18. 9.

155 Various inscriptions in Lüders 1912; Mirashi 1981.

156 Mirashi 1981, no. 11, 24, 27. Lüders 1912, nos. 1000, 1073.

157 Mirashi 1981, no. 38, 43.

158 An example of dedication of custom duties to a monastery comes from Godavaya, Sri Lanka. Muthucumarana et al. 2014, 43.

159 See also sec. V. 
illness in old age, and the property would go to the monastic community instead of being forfeited to the state on account of the absence of an heir. ${ }^{160}$

The monks (bhikkhu) and nuns (bhikkuni) had an important role in developing monasteries as depositories of material wealth. Various donative inscriptions indicate that monks and nuns possessed property and were able to make donations for the erection of sacred architecture. At Sanchi itself, almost 40 percent of the donors are monks and nuns. ${ }^{161}$ Other than being donors themselves, the monks and nuns brought in donations from the laity for the construction and maintenance of monastic structures. Donative inscriptions often give the names of monks and nuns who had influenced the lay devotees (śișya/śiśinī, upāsakas/upāsikā and atevāsinī). ${ }^{162}$

\section{VII.3 Roles of Monasteries in Local Communities}

As centers of wealth, monasteries could adopt relevant technologies, which is commonly visible in the adoption and popularization of written forms of recordkeeping, their involvement in water management projects, and their development as medical care centers. Moreover, the popularity of Buddhism throughout the subcontinent allowed monastic institutions to cater to the other specific socioeconomic needs of local people, such as their need for banking facilities. ${ }^{163}$ These were services that locals were able to avail by perhaps making donations.

Monasteries emerged as credit institutions, which is particularly visible in the Mūlasarvastivadi-vinaya. One passage reveals a discussion on lending money to others and the pledge to pay twice the value. ${ }^{164}$ However, what is stark about this section of the text is that it emphasizes the need for and importance of maintaining written credit notes and contracts. The passage presents a standard formula to be used when charting the contracts. This standardization is a response to losses when borrowers did not pay their debts. Even if the practice of maintaining written contracts did not start in monasteries, they had an important role in popularizing it in different areas of the subcontinent that had generally relied on oral agreements.

The involvement of monastic units in the management of water bodies and the use of technology associated with irrigational activities is discussed elsewhere in this volume. ${ }^{165}$ Monasteries also developed as centers of healing and medical practice, especially related to maternity care. ${ }^{166}$ Monasteries provided care to the sick in

160 For more about property of monks, leaving of a householder's life and old age renunciation to join the samgha for care, see Schopen 2004, 7-13.

161 Schopen 2004, 383.

162 Lüders 1912, nos. 57, 69a, 1295 and so on.

163 Shaw 2016, 535.

164 Schopen 2004, 48-49.

165 Dwivedi, ch. 10, VI.1, this volume.

166 For a detailed discussion on medical practices in Buddhist monasteries and further references, see Rees and Yoneda 2013. 
return for a donation and maternal care for women at various stages of pregnancy, such as providing contraceptives and fertility drugs to members of the laity, and providing childbirth assistance. ${ }^{167}$ Monasteries emerged as repositories of medical knowledge and skill that were compiled and reproduced in various Buddhist canonical texts. ${ }^{168}$ While monastic culture was a phenomenon that was pan-Indic, monasteries also interacted with local population at various levels and incorporated folk practices, such as village-level fertility- and mother-goddess cults. ${ }^{169}$

\section{Kings and Rulers}

The king should seek to acquire what he has not acquired, preserve diligently what he has acquired, augment what he has preserved, and distribute what he has augmented on worthy recipients. ${ }^{170}$

Along with guilds and monasteries, kings are among the most visible and consequential economic actors in early historic South Asia. As the quote demonstrates, a king's economic role as an appropriator, manager, and redistributor is clearly stated in normative and pedagogical texts of early historic India. Matters of economy ( $v \bar{a} r t t \bar{a})$ are some of the most vital parts of a prince's education system. ${ }^{171}$ Kings were seen as resource managers, acquiring and distributing property. The acquisition of resources is treated in ch. 10 of this volume. Here, I focus on how state resources were distributed to politically important organizations and institutions. In particular, kings invested a great deal in monumental architecture, the royal household, salaried officials, and the army. They also showed favor to certain groups through tax exemptions and, along with other members of the royal household, through donations to monasteries. In addition, however, the king and his state also influenced the economic behavior of others, both by setting an example and by urging certain types of behavior.

\section{VIII.1 Exempla}

Aśoka Maurya (mid-third century BCE) is one of the rulers who was a trendsetter as a consumer and mobilizer of resources. In his edicts, he not only instructs on the

167 Rees and Yoneda 2013.

168 Rees and Yoneda 2013, 265-266.

169 For Buddhism as an assimilator of local practices, see Shaw 2013; 2016. For a discussion on representations of fertility cult in monastic art, see Rees and Yoneda 2013.

170 MS 7. 99, trans. Olivelle 2005, 159.

171 According to the Arthaśāstra, vārttā (economy) consists of agriculture, animal husbandry, and trade; and these sectors are important as sources of grain, livestock, money, forest produce, and labor (KA, 1. 2. 1; MS 7. 43). Other subjects (vidyā) that a king should be well-versed in are ānvīkșiki (philosophy or critical enquiry), trayī (the three Vedas), and daṇaniti (governance). 
moral conduct of his subjects, ${ }^{172}$ but also directs their behavior as consumers. Aśoka forbids animal sacrifices, festivals, and ceremonies. He also recommends that it is "not only good to spend little, but to own the minimum of property." 173 Special officials were instructed to ensure that the recommendations and reasons were manifested to the public. ${ }^{174}$ He claims that he forbade the killing of thousands and thousands of animals for the royal kitchen's daily meat demand, and rather limited it to two peacocks and a deer, and even these were to be stopped in the future. ${ }^{175}$ Aśoka also praises the benefits of gift-giving (dāna) and recommends that people should make donations to śramaṇa (religious mendicants), Brāhmaṇas, and in favor of Dhamma. ${ }^{176}$ From the third century BCE onward, there is a stark increase in the number of donative inscriptions in the subcontinent, however, it is difficult to say how much of it was the result of Aśoka's instructions/promotion of gifting to Buddhist monasteries. Yet, scholars have noticed that the architecturally grand religious monuments were definitely post-Aśokan. ${ }^{177}$

\section{VIII.2 Donations and Favors}

Religious donation and expenses on rituals continued to play an important role in royal self-fashioning. By the third century $\mathrm{CE}$, six different inscriptions refer to kings having performed the Aśvamedha yajña. ${ }^{178}$ Other elaborate descriptions of ritual patronage and sacrifices offered by queens on behalf of their family members are also recorded in epigraphic material. One interesting example is Nāganika, a queen of the Sātavāhana king Sātakarṇi I. The reference comes from a cave inscription at Nanaghat (Maharashtra). For our studies, this inscription has two important components, a) the family ties mentioned and b) the elaborate listing of the various ritual sacrifices and payments. Nāganika identifies herself in relation to her various relatives by name, however only two of the relations and names are clearly decipherable, which are of her progenies Vediśrī and Śakti. These sacrifices not only incur the cost of the items required in the sacrifices, but the expenses given as sacrificial fees (dakșina $)$ are also grand. The inscription lists 17 Vedic sacrifices by name, a specific sacrificial fee (dakhin, Skt. dakșinā), and gifts given for each in cash as well as kind. ${ }^{179}$ In the Angārika sacrifice, Nāganika claims that one of the 17 sacrifices

172 Major Rock Edict (MRE) 3, 4, 9, 13 of Aśoka.

173 MRE 3. Trans. Thapar 2013, 377-378.

174 MRE 3.

175 In MRE 1.

176 MRE 9, 11, 13.

177 Schopen (2004, 1-2) writes that the Buddhist 'monasteries' in the pre-Aśokan period were perhaps unorganized natural caverns or poorly constructed shelters built of rubble.

178 Sircar 1971, 175.

179 Mirashi 1981, pt. 2, 11-16. For more on the concept of dakșiṇā, see Thapar (1978) $2006 a$. 
had a sacrificial fee of 11,000 cows, 1,000 horses, some portion of an excellent village, and a total of 34,401 kärșāpanas (a denomination of currency) to the sacrificial attendant. ${ }^{180}$

There are two more detailed inscription records where a head queen of the Sātavāhanas, Gautamī Bala-śrī, orders donations of land to the Buddhist monks. In one, she donates the land with her son, King Gautamīputra Sātakarṇi. In the other, a cave and village land are donated with her grandson, King Pulumāvi. ${ }^{181}$

Examples of donations from other members of the royal families are also common in the inscriptions, especially from the western India. One example is Rișabhadatta, son-in-law of the Kṣatrapa King Nahapāna, and comes from a cave inscription in Nasik. ${ }^{182}$ It boasts of a gift of gold, 300,000 cows and 32,000 coconut saplings, the feeding of 100,000 of Brāhmaṇas annually, residential houses at four cities/villages, the building of several gardens, water tanks and wells, the construction of charitable rest houses for travelers, and various other charitable works.

Kings could also perform such benefactions by redirecting revenue streams toward religious institutions. A cave inscription from Nasik records the donation of a village's fields and a portion (100 nivartanas) of royal fields to the mendicant monks dwelling in the cave on a particular hill by a king. ${ }^{183}$ His son, Pulumāvi, also adds another village to the existing donation for the same group of monks. He announces that all royal rights of enjoyment of the land are renounced and the donated land gets certain immunities, meaning the donated land should not be entered by royal officials, nor should the land be dug for salt. ${ }^{184}$ Another interesting case is an inscription of King Hamani Abaya, from Godavaya (Sri Lanka) in the second century CE. It refers to the donation of the custom duties from the port of Godavaya Pattanam to the nearby vihāra (monastic residence). ${ }^{185}$ Various other instances of the donation of revenues to monasteries have also been recorded in other inscriptions in Sri Lanka. ${ }^{186}$

Not all beneficiaries were monasteries. Kings could exempt individuals, families, and even villages from taxation, debts, fines, etc. One famous instance is recorded in the Rummindei inscription issued by Aśoka. The inscription records the exemption of the village of Lumbinī, the birthplace of the Buddha, from the payment of tribute (bali) to the state. It also announces the reduction of the tax to

180 Mirashi 1981, pt. 2, 15-16. The eligibility of a priest and other attendants to qualify as participants in the sacrificial ceremonies has been discussed in detail in the Manusmrti. The eligibility of the performing priests and the client is to be determined by their 'ritual competency' (adhikāra).

181 Mirashi 1981, pt. 2, 34-35, 48-49.

182 Mirashi 1981, pt. 2, 111-113, see inscription no. 43.

183 Mirashi 1981, pt. 2, 34-35.

184 Mirashi 1981, pt. 2, 48-49, 53-55.

185 Muthucumarana et al. 2014, 43.

186 Paranavitana 1970, no. 1216, 99. 
one-eighth of the produce (atthhabhāga) for the village. ${ }^{187}$ From the Hathigumpha inscription, we also learn that King Khāravela celebrated his consecration as the king by remitting all tithes and cesses, and bestowed many privileges amounting to hundreds of thousands (of an undefined monetary denomination). ${ }^{188}$ Most performances of royal largesse, however, were targeted at particular locations and institutions. Monasteries, in particular, profited handsomely.

\section{VIII.3 Monumental Construction}

Aśoka also mobilized significant resources in monumental construction, as is clear from the edicts found in pan-Indic contexts, except in the southernmost parts of the subcontinent. ${ }^{189}$ The Aśokan pillars are royal monuments that required the procurement of the raw material from a quarry, sculpting of the pillars and capitals, technological expertise to polish and coat the surface of the pillars, and transportation to their sites of erection. ${ }^{190}$ Further, also installation at sites required expertise, as they weigh from 8.6 tons (Lumbini) to 51 tons (Vaishali), and with their sculpted capitals that weighed around 2 tons each. ${ }^{191}$ The pillars are made of Chunar sandstone obtained for quarries at the Chunar Hills, and their respective sites of erection indicate a clustering in the northern part of middle Ganga Plain, connecting the resource area and sites through riverine navigational channels. ${ }^{192}$

Aśoka is not the only ruler who erected monuments. A biographical inscription of King Khāravela (first century BCE), of Kalinga, declares him the "repairer of temples," and he is lauded for the construction of a royal residence called the Palace of Great Victory (Mahāvijaya) for a cost of 38 hundred thousand (unspecified denomination of money). He also built excellent towers with carved interiors and repaired the gates of his capital. ${ }^{193}$

\section{VIII.4 The Palace and the Royal Household}

The king's palace, too, required significant investment. Literary sources are replete with normative or rhetorical descriptions of the monumentality and material extra-

187 Thapar 2013, 84-85. The reading of the term aṭhabhāga/ațhabhāgiya, however, is disputed. Falk (2012) agrees that the village was made tax-free, however suggests the term ațhabhägiya does not mean reduction of taxes from one-sixth to one-eighth. He points out that the term suggests that Lumbinī would receive a one-eighth share of the ashes of the Buddha as relic.

188 K. P. Jayaswal and Banerji 1929; Kant 2000 12, 26.

189 See Dwivedi, vol. 1, ch. 10.A, map 1.

190 V. Jayaswal 2012.

191 Falk 2006, 139.

192 V. Jayaswal 2012, 230, 243-250.

193 Kant 2000, 18-19, 30. 
vagance of rājaparigraha, the royal property and palace grounds. ${ }^{194}$ They are depicted as large complexes of dwellings and are represented in literature as bhavana, antahpura, niveśa, prāsāda, and harmya. One of the descriptions of an extravagant residence includes "emerald flooring, tiles studded with rubies, the garden, vine creeper bowers, the house of shower baths and the palaces with secret passages between walls, murals, the royal pastimes, mechanical devices, birds, caged tigers and lions and other such things." 195 The space of the palace is divided to cater for the daily royal routines with separate buildings for dressing, bathing, feasting, courtship, and counsel. The palaces have various rooms for different activities (garbha and kakșa) and various quarters or courtyards (kakșya). ${ }^{196}$

Such opulent building complexes houses not only the royal household, consisting of the king's immediate and extended family members (many of whom enjoyed salaried positions), ${ }^{197}$ but a large support staff as well. The palace includes residences for priests and ministers, a maternity ward, worker's quarters, treasury, storehouse, armory, stables, etc. We find references to a large number of servants and perhaps slaves as well, employed in the service of royal household. We learn of female servants, called kañcuki and mahattarikā, who are the attendants in the harem, and take the messages and items from the harem to the king. ${ }^{198}$ The palace, then, was a large, complex institution requiring significant expenditure for its construction, upkeep, and operation.

\section{VIII.5 Salaries}

Monarchical states also distributed resources in the form of salaries to various individuals. In addition to members of the royal household, Mauryas and post-Mauryan polities exhibit elaborate administrative machineries with a number of managerial and mid-managerial level roles. As I am discussing below, the salaried positions of accountants, scribes, supervisors, and other skilled officers gave them the potential spending capacity to stimulate the use of coined money. ${ }^{199}$

We also learn about the hierarchical organization in the army, along with recommended salaries in cash. At Karari an inscription on wood lists the presence of various state officials during the commission of a tank, which also includes the

194 Ali 2004, 38. KA 2. 36. 22; 2. 36. 28.

195 KS 5. 5. 17, trans. Upadhyaya 1961.

$196 K A$ 1. 20.13; 1. 21. 3. For depictions of royal architecture in the Rāmāyaṇa, see Guruge 1991, 97. 197 The crown prince (yuvarāja), king's mother (rājamātr), and the crowned queen (rājamahiși) are listed as those entitled to highest scale of salary, i.e., 48,000 panas. Other members of the royal household recommended for a salary of 12,000 panas are the princes and the mothers of princes. KA 5. 3. 3, 7.

$198 K S$ 4. 2. 73. In some versions $K S$ 4. 2. 56.

199 Dwivedi, ch. 14, III.6; see also Smith 2018. 
names of the senāpati (Chief of the Armed Forces), two nagarakhins (city guards/ police inspectors), yānaśālayudhagharika (officer in charge of carriage-shed and armory), and the mahāsenānī (commander-in-chief), among others. ${ }^{200}$

The highest-ranked military official is the senappati (Chief of the Armed Forces), who is among the highest-paid state officials, with a recommended salary of 48,000 panas. ${ }^{201}$ The chiefs of the four divisions of the army (infantry, chariots, horses, and elephants) have a recommended salary of 8,000 panas, while the superintendent of these units, who are responsible for acquisition and recruitment, are each to be paid 4,000 panas. Below them are the charioteers, and elephant and horse trainers, who are recommended for a salary of 2,000 panas. The salary recommended for trained foot soldiers is 500 panas. ${ }^{202}$ In addition to the base salary, at the battle array the army is to be roused by the Chief of the Armed forces with a promise of the following rewards:

100,000 Panas for killing the king; 50,000 Panas for killing the Chief of the Armed Forces or the Crown Prince; 10,000 Panas for killing the leaders of eminent warriors; 5,000 Panas for killing an elephant or chariot fighter; 1,000 Paṇas for killing a cavalryman; 100 Panas for killing a leader of infantry; and 20 per head; and in addition, double the pay and individual plunder. $^{203}$

We are not aware of the actual size of the army, but representative numbers from different sources would indicate that a good number of men were involved, and their monetary recompense indicates that they participated in monetary transactions. ${ }^{204}$

\section{The Army}

The economic impact of royal armies went well beyond soldiers' and officers' salaries. The expansion of his kingdom was a king's most important activity, and the

200 Sastri 1925.

$201 K A$ 5. 3. 3.

$202 K A$ 5. 3. 9, 11, 14.

$203 K A$ 10. 3.45 trans. Olivelle 2013 , 379. The next verse ( $K A$ 10. 3. 46) states that the officer of his unit shall certify the claim by a soldier of his kills.

204 The largest regiment in Indic sources is mentioned as the akșauhini comprising of perhaps more than 200,000 units (U. P. Thaplyal 2002, 77). The size of army mentioned in Graeco-Roman Indographies are different. Diodorus and Curtius mention that the army comprised of 20,000 cavalrymen, 2,000 chariots, and 4,000/3,000 elephants. Plutarch mentions that Candragupta Maurya subdued India with an army of 80,000 horses, 200,000 foot soldiers, 8,000 chariots, and 6,000 elephants (Plutarch Life of Alexander 62. 3; Pliny Naturalis historia 6. 22. 67; Majumdar [1960] 1981, 192-193, 198). These numbers are daunting considering Alexander had some 5,000 cavalrymen, and between 9,000 to 10,000 heavy and light infantry soldiers (Roy 2016, 12-13). 
army formed the most important means to that goal. ${ }^{205}$ The term danda means 'army' and 'police,' which are the apparatuses of enforcement. Vigraha (declaration of hostility) and yāna (marching into battle) are two of the six measures of foreign policy. ${ }^{206}$ Declaration of war is noted as a common solution to the problems with the neighboring kingdoms, and kings should plan well economically. As warfare is one the most expensive affairs a state could carry out, a king is directed to declare war only when he foresees certain gains and advantages for the forts, irrigation works, trade routes, settlements in wastelands, and acquisition of forests with resources and mines. ${ }^{207}$

The economic implications of an army are many. It was an instrument of subjugation and acquisition of land, labor, and tribute. Additionally, an army was both a mobilizer of human resources and a consumer. For a polity, either pre-state or empire-like, the army as a professional unit was an absorber of human resources. In normative and prescriptive texts, the maula (hereditary troops) is described as the core of an army, which perhaps was the state's standing army. ${ }^{208}$ The presence of an organized professional army meant that thousands of able-bodied men were withdrawn from other economic activities, and the impact of maintaining a standing army was particularly noticeable. Theoretically, the organization of a standing army implies the presence of a treasury built on regular tax collection and/or tributes for recruiting and training full-time soldiers. ${ }^{209}$

Warfare drove economic activity through more than just the maula. There were five other types of units in an army: the mercenaries or hired troops (bhrta), the guild levies or the corporate troops (śreṇi), the ally's troops (suhrdbalam), the troop of captured or troop from the enemy (davișadbalam), and the troops of forest tribe (atavībalam).210 Other than these troops, we hear of the autsāhika, who are the groups of fighters or vandals that are not paid but fight for booty, ${ }^{211}$ and āyudhajivisamgha, those "making a living by the profession of arms."212

205 See the concept of vijigịșu in Dwivedi, vol. 1, ch. 3, 109. As the vijigịșu is the type of 'king bent on conquest' and the 'universal conqueror.' $K A$ 6. 2. 13.

$206 K A$ 7. 1. 2. The other four strategies are, peace pact, staying quiet or remaining stationary, seeking refuge, and double stratagem. See Kangle (1969) 2014b, 321; Olivelle 2013, 277. See also MS 7. 162.

207 KA 7. 1. 20.

208 The maula type of soldiers basically refers to the soldiers of a kingdom or region, who are native to the region and also constitute the core of the army. Kangle suggests that the etymology conveys a sense of hereditary connection of the troops, who are loyal to the dynasty from generation after generation (Kangle [1969] 2014b, 409, n. 2).

209 For a discussion on standing army as a prerequisite of a state system in early historic South Asia, see Thapar 1992, 112-113.

$210 K A$ 9. 2. 1.

$211 K A$ 9. 2. 9.

212 These groups are discussed in the Sanskrit grammatical work, the Așțādhyāyī, of Pāṇini. See Agrawala 1953, 422, 434-442. The $K A$ also mentions a āyudhīya-prāyah, explained as āyudhajīviKșatriyādi-pracurāḥ, those mostly comprising soldiers, Agrawala 1953, 434. 
South Asian armies had complex organizational structures that often required specialized equipment and training, which further increased military costs. The most common organizational types were caturanga-bala and caturang-vāhini, which referred to the traditional fourfold division of the army, including infantry, chariots, cavalry, and elephant corps. ${ }^{213}$ Moreover, in special instances, we also come across references to the 'six-fold' and 'eight-fold' divisions of the army. The six-fold army includes 'treasure' (koșa) and 'machines' (yantra). The 'eight-fold' army is more elaborate, as it also has officers, spies, military guides, and workmen like mechanics, tunnel makers, bridge builders, etc. ${ }^{214}$

Specialized units required not only equipping the soldiers with weapons and armor, but also with the acquisition and training of horses and elephants for warfare. The fascination of Greek Indographers with the usage of elephants in Indian warfare is well noted. ${ }^{215}$ However, the Arthaśāstra provides a better picture of processes involved in acquiring elephants for war purposes. The Arthaśāstra refers to designated officers, aśvādhyakșa ('superintendent of horses') and hastyādhyakșa ('superintendent of elephants'), for the acquisition of war animals. ${ }^{216}$ Further, we find references to special forests designated as the resource centers for elephants (hastivana and nāgavana). ${ }^{217}$ The process of acquisition of elephants from the forested region also indicates interesting dynamics in the relationship between the state and the inhabitants of forests. ${ }^{218}$ Further, the maintenance of elephants involves heavy costs, the most basic of which is food at a minimum of $150 \mathrm{~kg}$ daily per elephant when in the wild. It is suggested that a captive elephant must be fed higher-energy rations to enable the heavier workload. ${ }^{219}$ Considering that not only does acquiring and training war animals require resources, even the march to the battleground and time at the war camps would have been expensive. A retinue of more than 14 specialized attendants for elephants is listed in the Arthaśāstra, which consists of a veterinarian, a trainer, a groom, a guard, a feeder, and other personnel. ${ }^{220}$ The ideological and practical importance of warfare to Indic kingship, and perhaps the political plurality of the subcontinent, ensured that the bulk of royal resources usually flowed to the army.

$213 K A$ 10. 4. 15. Similar division of the army has also been mentioned in the Hathigumpha inscription of Khāravela (ca. 172 BCE). See Kant 2000.

214 P. C. Chakravarti 1941, 2, n. 1; U. P. Thaplyal 2002, 84-85.

215 Trautmann 2009.

$216 K A$ 2.30; 2. 31.

217 KA. 1. 10. 15; 2. 1. 19; 2. 2. 6.

218 Parasher-Sen 1998.

219 Trautmann 2015, 54.

220 KA 2. 32. 15-16. 


\section{$\mathrm{X}$ Conclusion}

The Indic economy was shaped by many different socioeconomic actors. As discussed in ch. 14 of this volume, kings and their states, monasteries, and corporate bodies were particularly important catalysts of change. But these cannot be understood in isolation. Households and manual laborers formed the foundation on which these larger organizations were built. Local elites played important interfacing roles, and settlements provided the physical and institutional framework within which they operated. Furthermore, these actors all operated in conjunction with one another, though not always in an intentionally coordinated manner. Monetization, for example, was driven by the coin production not only of civic bodies but also of guilds, while monasteries and guilds both functioned as credit institutions. ${ }^{221}$ Finally, the influence of an economic actor was not constant in all regions and spheres. At political centers, the state's influence was more direct in managing transport and hydraulic infrastructure, while in central India and the Deccan, the Buddhist monasteries tended to the local needs of infrastructural requirements. It is the articulation of these actors' various behaviors that drove the economy in early historic South Asia. The institutions and structures that facilitated and resulted from that articulation are the subject of the chapter on South Asian Tools.

\section{References}

Agrawala, V. S. 1953. India as known to Pạnini (A study of the cultural material in the Ashțādhyāyī). Lucknow: University of Lucknow.

Ali, D. 2004. Courtly culture and political life in early medieval India. Cambridge: Cambridge University Press.

Allan, J. 1936. Catalogue of coins of ancient India in the British Museum. London: British Museum. Apte, V. S. 1993. The student's English-Sanskrit dictionary. 3rd ed. New Delhi: Motilal Banarasidass.

Basant, P. K. 2012. The city and the country in early India: A study of Malwa. New Delhi: Primus Books.

Chakravarti, P. C. 1941. The art of war in ancient India. Dacca: The University of Dacca.

Chakravarti, R. 1996. "Kutumbikas of early India." In V. K. Thakur, A. Aounshuman, and R. Choudhary (eds.), Peasants in Indian history: Theoretical issues and structural enquiries (Essays in memory of Professor Radhakrishna Chaudhary). Vol. 1, 179-198. Patna: Janaki Prakashan.

-. 2007. "Rājaśreșthī." In R. Chakrravarti, Trade and traders in Early Indian society, 102-112. New Delhi: Manohar.

Chakravarti, U. 1996. "In search of the peasant in early India: Was the gahapati a peasant producer?" In V. K. Thakur and A. Aounshuman (eds.), Peasants in Indian history: Theoretical

221 For more on monetization, see Dwivedi, ch. 10, III, this volume. 
issues and structural enquiries (Essays in memory of Professor Radhakrishna Chaudhary). Vol. 1, 150-178. Patna: Janaki Prakashan.

-. 2006. "Of dasas and karmakaras: Servile labour in ancient India." In U. Chakravarti, Everyday lives, everyday histories: Beyond the kings and Brahmanas of 'ancient' India, 70-100. New Delhi: Tulika Books.

Champakalakshmi, R. 1996. Trade, ideology and urbanization: South India 300 BC to AD 1300. Delhi: Oxford University Press.

Chanana, D. R. 1960. Slavery in ancient India: As depicted in Pali and Sanskrit texts. New Delhi: People's Publishing House.

Cohen, S. P. 1964. "Rulers and priests: A study in cultural control." Comparative Studies in Society and History 6.2, 199-216.

Coningham, R. A. E., F. R. Allchin, C. M. Batt, and D. Lucy. 1996. "Passage to India? Anuradhapura and the early use of the Brahmi script." Cambridge Archaeological Journal 6.1, 73-97.

Cowell, E. B., ed. 1977. The Jātaka, or stories of the Buddha's former births. 6 vols. Oxford: Clarendon Press.

Deloche, J. 1983. "Geographical considerations in the localisation of ancient sea-ports of India." The Indian Economic \& Social History Review 20.4, 439-448.

-. 1994. Transport and communications in India prior to steam locomotion. J. Walker (trans.). Vol. 2, Water transport. Delhi: Oxford University Press.

Doniger, W. and S. Kakar, trans. 2002. Vatsyayana Kamasutra. Oxford: Oxford University Press. Dwivedi, M. 2015. "Understanding Artha: Pursuit of wealth in the Ganga-Yamuna Doab (c. BC 200 to AD 400)." PhD diss., Jawaharlal Nehru University.

Evers, K. G. 2017. Worlds apart trading together: The organisation of long-distance trade between Rome and India in antiquity. Oxford: Archaeopress.

Falk, H. 2006. Aśokan sites and artefacts. A source-book with bibliography. Mainz: Philipp von Zabern.

-. 2012. "The fate of Aśoka's donations at Lumbinī." In P. Olivelle, J. Leoshko, and H. P. Ray (eds.), Reimagining Aśoka: Memory and history, 204-216. New Delhi: Oxford University Press.

Furubotn, E. G. and R. Richter. 2005. Institutions and economic theory: The contribution of the New Institutional Economics. 2nd ed. Ann Arbor, MI: University of Michigan Press.

Ghosh, S. 2014. "Barbarikon in the maritime trade network of early India." In R. Mukherjee (ed.), Vanguards of globalization: Port cities from the classical to the modern, 59-74. New Delhi: Primus Books.

Ghoshal, U. N. 1944. The beginnings of Indian historiography and other essays. Calcutta: Ramesh Ghoshal.

Heesterman, J. C. 1982. "Householder and wanderer." In T. N. Madan (ed.), Way of life: King, householder, renouncer. Essays in honour of Louis Dumont, 251-271. Delhi: Vikas Publishing.

Horner, I. B., trans. (1952) 2001. The book of the discipline (Vinaya-Pitaka). Vol. 5, Cullavagga. Oxford: The Pali Text Society.

Jaiswal, S. 2001. "Female images in the Arthasastra of Kautilya." Social Scientist 29.3/4, 51-59.

Jamison, S. W. 2017. "Marriage and the householder." In P. Olivelle and D. R. Davis (eds.), The Oxford history of Hinduism: Hindu law: A new history of Dharmaśāstra, 125-136. Oxford: Oxford University Press.

Jayaswal, K. P. and R. D. Banerji. 1929. "The Hathigumpha inscription of Kharavela." Epigraphia Indica 20, 71-89.

Jayaswal, V. 2012. "Mauryan pillars of the middle Ganga plain: Archaeological discoveries of Sarnath-Varanasi and Chunar." In P. Olivelle, J. Leoshko, and H. P. Ray (eds.), Reimagining Aśoka: Memory and history, 229-257. New Delhi: Oxford University Press.

Kangle, R. P., trans. (1969) 2014a. The Kauțilīya Arthaśāstra. Vol. 1, Sanskrit text. Delhi: Motilal Banarsidass. 
-. (1969) 2014b. The Kauțilīya Arthaśāstra. Vol. 2, Translation. Delhi: Motilal Banarsidass.

Kant, S. 2000. The Hathīgumphā inscription of Khāravela and the Bhabru edict of Aśoka: A critical study. 2nd ed. New Delhi: D. K. Printworld.

Kocks, J. N. 2016. Political media relations online as an elite phenomenon. New York, NY: Springer.

Krishna Rao, M. V. 1953. Studies in Kautilya. Mysore: H. Venkataramiah.

Lahiri, B. 1974. Indigenous states of northern India (circa 200 BC to 320 AD). Calcutta: University of Calcutta.

Liu, X. 2009. "Buddhist ideology and the commercial ethos in Kuṣāna India." In J. Hawkes and A. Shimada (eds.), Buddhist stupas in South Asia. Recent archaeological, art-historical, and historical perspectives, 117-191. New Delhi: Oxford University Press.

Lüders, H. 1912. A list of Brahmi inscriptions from the earliest times to about AD 400 with the exception of those of Asoka. Calcutta: Superintendent Government Printing.

Majumdar, R. C. (1960) 1981. The classical accounts of India: Being a compilation of the English translations of the accounts left by Herodotus, Megasthenes, Arrian, Strabo, Quintus, Diodorus, Siculus, Justin, Plutarch, Frontinus, Nearchus, Apollonius, Pliny, Ptolemy, Aelian, and others with maps. Calcutta: Firma K. L. Mukhopadhyay.

Mandal, K. K. 2007. "Note: Forms of peasant protest in the 'Jatakas." Social Scientist 35.5/6, 3946.

Milligan, M. D. 2019. "The economic power of women in early South Asian Buddhism." The Indian Economic \& Social History Review 56.1, 53-76.

Mirashi, V. V. 1981. The history and inscriptions of the Sātavāhanas and the Western Kshatrapas. Bombay: Maharashtra State Board for Literature and Culture.

Moorti, U. S. 1994. Megalithic culture of South India: Socioeconomic perspectives. Varanasi: Ganga Kaveri Publishing House.

Muthucumarana, R., A. S. Gaur, W. M. Chandraratne, M. Manders, B. R. Rao, R. Bhushan, V. D. Khedekar, and A. M. A. Dayananda. 2014. "An early historic assemblage offshore of Godawaya, Sri Lanka: Evidence for early regional seafaring in South Asia." Journal of Maritime Archaeology 9.1, 41-58.

Neelis, J. E. 2011. Early Buddhist transmission and trade networks: Mobility and exchange within and beyond the northwestern borderlands of South Asia. Leiden: Brill.

Olivelle, P. 1993. The Āśrama system: The history and hermeneutics of a religious institution. Oxford: Oxford University Press.

-, trans. 1999. Dharmasūtras: The law codes of Āpastamba, Gautama, Baudhāyana, and Vasișța. Oxford: Oxford University Press.

-, trans. 2005. Manu's code of law: A critical edition and translation of Mānava-Dharmaśāstra. Oxford: Oxford University Press.

-, trans. 2013. King, governance, and law in ancient India: Kauțilya's Arthaśāstra: A new annotated translation. Oxford: Oxford University Press.

Paranavitana, S. 1970. Inscriptions of Ceylon. Vol. 1, Containing cave inscriptions from $3 r d$ century $B C$ to 1 st century $A D$ and other inscriptions in the early Brāhmī script. Ceylon: Department of Archaeology.

Parasher-Sen, A. 1998. "Of tribes, hunters and barbarians: Forest dwellers in the Mauryan period." Studies in History 14.2, 173-191.

Rajan, K. 2019. Churning the ocean: Maritime trade of early historic peninsular India. Thanjavur: Manoo Pathippakam.

Ray, H. P. 1986. Monastery and guild: Commerce under the Sātavāhanas. Delhi: Oxford University Press.

-. 2006. "Inscribed pots, emerging identities: The social milieu of trade." In P. Olivelle (ed.), Between the empires: Society in India 300 BCE to 400 CE, 113-144. Oxford: Oxford University Press. 
-. 2020. Coastal shrines and transnational maritime networks across India and Southeast Asia. London: Routledge.

Rees, G. and F. Yoneda. 2013. "Celibate monks and foetus-stealing gods: Buddhism and pregnancy at the Jetavana Monastery, Shravasti, India.” World Archaeology 45.2, 252-271.

Roy, K. 2016. Military manpower, armies and warfare in South Asia. London: Routledge.

Sahoo, P. C. 2012-2013. "Slavery, Manu and human rights." Bulletin of the Deccan College Research Institute 72/73, 451-456.

Sastri, H. 1925. "Brahmi inscription on a wooden pillar from Kirari." Epigraphia Indica 18, 152157.

Schlingloff, D. 2013. Fortified cities of ancient India: A comparative study. London: Anthem.

Schopen, G. 1994. "The monastic ownership of servants or slaves: Local and legal factors in the redactional history of two Vinayas." Journal of Buddhist Studies 17.2, 145-175.

-. 2004. Buddhist monks and business matters: Still more papers on monastic Buddhism in India. Honolulu, HI: University of Hawai'i Press.

-. 2008. "Separate but equal: Property rights and the legal independence of Buddhist nuns and monks in early north India." Journal of the American Oriental Society 128.4, 625-640.

-. 2010. "On incompetent monks and able urbane nuns in a Buddhist monastic code." Journal of Indian Philosophy 38.2, 107-131.

Seshan, R. 2007. "Writing the nation in India: Communalism and historiography." In S. Berger (ed.), Writing the nation: A global perspective, 155-178. London: Palgrave Macmillan.

Sharma, R. S. 1990. Súdras in ancient India: A social history of the lower order down to circa $A D$ 600. 3rd ed. Delhi: Motilal Banarsidass.

Shaw, J. 2013. "Archaeologies of Buddhist propagation in ancient India: 'Ritual' and 'practical' models of religious change." World Archaeology 45.1, 83-108.

-. 2016. "Religion, 'nature' and environmental ethics in ancient India: Archaeologies of human:non-human suffering and well-being in early Buddhist and Hindu contexts." World Archaeology 48.4, 517-543.

Shimada, A. 2013. Early Buddhist architecture in context: The great stūpa at Amarāvatī (ca. 300 BCE-300 CE). Leiden: Brill.

Sircar, D. C. 1966. Indian epigraphical glossary. Dehli: Motilal Banarsidass.

-. 1971. Studies in the religious life of ancient and medieval India. Delhi: Motilal Banarsidass.

Smith, M. L. 2006. "The archaeology of South Asian cities.” Journal of Archaeological Research 14.2, 97-142.

-. 2018. "Urbanism and the middle class: Co-emergent phenomena in the world's first cities." Journal of Anthropological Research 74.3, 299-326.

Srinivasan, S. 2018. "Early gold mining and jewellery: Some insights from the Nilgiris, Tamil Nadu and Karnataka." SAARC Culture 6, 88-102.

Thakur, P. 2018. "Floral jewellery in ancient Indian tradition." SAARC Culture 6, 79-87.

Thakur, V. K. 1987. "Role of guilds in ancient Indian urban administration (c. 200 BC-C. AD 600): A numismatic study." Journal of the Numismatic Society of India 49, 70-76.

Thapar, R. 1982. "Householders and renouncers in the Brahmanical and Buddhist traditions." In T. N. Madan (ed.), Way of life: King, householder, renouncer: Essays in honour of Louis Dumont, 273-298. New Delhi: Vikas Publishing.

-. 1992. From lineage to state: Social formations in the mid-first millennium $B C$ in the Ganga valley. 2nd ed. Delhi: Oxford University Press.

-. (1978) 2006a. "Dāna and dakșināa as forms of exchange.” In Ancient Indian social history: Some interpretations, 94-108. New Delhi: Orient Longman.

-. (1978) 2006b. "Social mobility in ancient India with special reference to elite groups." In Ancient Indian social history: Some interpretations, 122-151. New Delhi: Orient Longman.

-. 2013. Aśoka and the decline of the Mauryas. 3rd ed. New Delhi: Oxford University Press. 
Thaplyal, K. K. 1996. Guilds in ancient India: A study of guild organization in northern India and western Deccan from circa 600 BC to circa 600 AD. Delhi: New Age International.

Thaplyal, U. P. 2002. "Military organization in the ancient period." In S. N. Prasad (ed.), History of science, philosophy and culture in Indian civilization. Vol. 10.3, 68-103. New Delhi: Motilal Banarasidass.

Trautmann, T. R. 2009. "Elephants and the Mauryas." In T. R. Trautmann (ed.), The clash of chronologies: Ancient India in the modern world, 229-254. Delhi: Yoda Press.

-. 2015. Elephants and kings: An environmental history. Chicago, IL: University of Chicago Press. Tyagi, J. 2007. "Organized household production and the emergence of the Sangha." Studies in History 23.2, 271-287.

-. 2008. Engendering the early household: Brahmanical precepts in the early Gṛhyasuttras, middle of the first Millenium BCE. New Delhi: Orient Longman.

Upadhyaya, S. C., trans. 1961. Kama Sutra of Vatsyayana: Complete translation from the original Sanskrit. Bombay: Taraporevala Sons \& Co.

Varma, S. and J. Menon. 2011. "Children playing and learning: Crafting ceramics in ancient Indor Khera." Asian Perspectives 49.1, 86-109.

-. 2015. "Mapping histories and practices of potters' households in ancient Indor Khera (200 BCE-500 CE)." In K. Roy (ed.), Looking within, looking without: Exploring households in the subcontinent through time: Essays in memory of Nandita Prasad Sahai, 19-45. Delhi: Primus Books.

Wagle, N. K. 1995. Society at the time of the Buddha. 2nd ed. Bombay: Popular Prakashan. 